There is, in my view, a potentially devastating consequence of privatization in Africa-its effects on the regulatory regimes of governments, particularly in the areas of social welfare, health, safety, labor relations and the like. Current regulation of these areas is quite lax. Deficiencies are often made up by the fact that the ultimate employer is itself the government; thus, employees can bring pressure to bear directly through strikes or political agitation. Privatization, however, removes this direct mechanism of assuring minimal responsiveness by governments. We may fairly ask whether the weak regulatory regimes characteristic of many African governments will be up to the task of acting as a dispassionate arbiter in conflicts between the new private owners and their workers, or between the new private owners and those on whom they would seek to shift any costs that can be readily externalized. Nothing in the privatization process suggests African governments are aware of this potential source of difficulty. If they are, they do not appear to be doing anything about it.

\title{
Privatization of Public Enterprises in Latin America
}

\section{By Rafael A. Porrata-Doria, Jr.*}

For the last three decades, most governments in Latin America have embraced the model of import substitution and promoted extensive state investment and ownership in undercapitalized or underdeveloped industries that have been perceived as valuable or desirable vehicles for national economic development.

The management of these state-owned or -controlled enterprises is accountable to a number of different constituencies (such as government bureaucracies, public employees, unions and consumers) with different (and inconsistent) political, social and economic objectives and management philosophies. Furthermore, after decades of public control, these enterprises are generally viewed as poorly managed, unprofitable, overstaffed, inefficient and noncompetitive in today's global economy. Lastly, governments in the region find that these enterprises represent an unacceptable drain on the public treasury. Many governments have therefore undertaken programs to privatize their extensive holdings of public enterprises.

This presentation will first discuss the principal motivations expressed by Latin American governments for their privatization of public enterprises. I will then describe in general the process of privatization in the region, based on the experiences of Argentina, Brazil and Mexico. Finally, I will comment on the success of these privatization programs and consider the possibility that an "international law of privatization" is emerging in Latin America.

\section{Reasons for Latin American Privatization Programs}

In rough order of priority, the following is a distillation of the justifications most governments in Latin America have given for their privatization programs.

1. "I'm broke and I need the money." The economic literature uniformly indicates that the governments of most states in Latin America emerged out of the 1970s and 1980s with a crushing debt burden that they could not pay, or even service. This debt crisis has engendered a scramble for solutions. Attempts to reduce governmental debt have included additional borrowing from multinational institutions like the World Bank, debt restructuring agreements, debt-equity swaps, tax increases, service cuts and economic austerity measures. These mecha-

\footnotetext{
* Temple University School of Law.
} 
nisms have succeeded in reducing the Latin American debt to some degree but have not been able to eliminate it.

Another result of the Latin American debt crisis is that many governments in the region find themselves with insufficient funds to pay for normal governmental operations, maintain their nation's infrastructure and operate their many public industries. There is a limit to how much a government can increase taxes or borrow from multinational or private institutions, and the only other source of funds for a government is to sell off its public industries for the highest possible price.

This motivation is cited in the privatization statutes of Argentina, Brazil and Venezuela as a specific purpose of privatization. Indeed, the Argentinian statute goes so far as to declare a "state of economic emergency" as the justification for its privatization program.

2. "The World Bank and the IMF made me do it." Other speakers have already discussed the World Bank and International Monetary Fund financing programs in Latin America and these institutions' ideological support of governmental policies involving free trade and financial and governmental deregulation.

The World Bank has generally undertaken two types of financing in the region: project financing and structural adjustment loans. The latter are intended to support economic reform within a particular sector of the borrowing state's economy, such as financial deregulation or agricultural price reforms. ${ }^{1}$

The World Bank, in making structural adjustment loans, specifies in its loan documents, as conditions for the disbursement of funds, a series of governmental policies that a country must promise to implement. One of these is a program of privatization of public enterprises. Furthermore, countries wishing to participate in debt relief programs and trade agreements under the United States Enterprise for the Americas Initiative are required to sign an agreement with the International Monetary Fund and participate in a World Bank structural adjustment loan. Thus, governments wishing to borrow from the World Bank have no option but to privatize their public industries.

3. "My consumers are fed up." Publicly held enterprises usually have either a monopoly or a series of competitive preferences in the supplying of goods or services to the local economy. Since these enterprises usually feature poor service, high prices and low-quality products, consumer dissatisfaction with public enterprises is usually high and, correspondingly, profits are low or nonexistent.

In order to assuage these consumer complaints, the government "owner" of an enterprise must improve product quality and service and establish competitive prices. These goals usually require a significant financial investment to improve the enterprise's technology and infrastructure, and neither the government nor the public enterprise has (or can borrow) the sums required. Accordingly, the only way in which product quality and service can be improved (and consumers assuaged) is substantial investment by a private entity (foreign or domestic). Such an investment is unlikely unless the investor can control the enterprise in order to make it profitable and recover its investment. Thus, selling the enterprise becomes a necessity.

4. "Everybody else is doing it." A number of governments in Latin America have experienced substantial success in their privatization programs. For example, the Mexican Government has, since 1988, sold a number of public enterprises worth $\$ 22$ billion at very good prices. Similarly, Argentina is expected to receive

\footnotetext{
${ }^{1}$ In 1991, structural adjustment loans constituted approximately 30 percent of the $\$ 5.2$ billion loaned by the World Bank to various Latin American countries, chiefly Mexico and Brazil.
} 
$\$ 13$ billion from its privatization program in the next few years, substantially reducing its debt. Nothing succeeds like success. A number of governments throughout Latin America have thus begun to copy the Argentine and Mexican privatization programs, which have become models throughout the region.

\section{The Process of Privatization}

The privatization process in Latin America is generally based on legislation that includes five major operational areas. The legislation (1) establishes a legal framework for privatization; (2) identifies the targets of privatization; (3) sets forth the process for valuing the enterprise to be privatized and prepares it for sale; (4) identifies the potential purchasers of the enterprise; and (5) sets the sales process. Let us briefly examine each of these operational areas.

1. Establishing the Legal Framework for Privatization. The legislation generally states that important social and economic needs require the privatization of public enterprises and that the process of privatization itself must be flexible, efficient and honest. It then identifies the entity that will supervise the privatization process. This entity may be either a national commission with extraordinary powers (Mexico), the Executive (Argentina), or even a trustee appointed to supervise the privatization of an individual industry (Argentina).

The supervising entity is generally assigned great power and enormous flexibility in establishing the working rules and procedures for the privatization process. As a protection against charges of fraud or corruption, these working rules should provide for the highest possible public visibility of the supervising entity and of the privatization process, and for the maximum possible competition in the bidding for the enterprises to be privatized.

2. Identifying the Targets of the Privatization Process. Most of the governments engaging in the privatization process own a large number of enterprises and may not desire to sell all of them. Accordingly, identification of public enterprises to be privatized is a major step in the privatization process.

The privatization statutes generally provide for one of three mechanisms for identifying the enterprises to be privatized. First, the statute itself can provide the list of enterprises, as in Argentina. Secondly, as in Brazil, the statute can delegate to the Executive the power to designate the entities to be privatized by decree. Lastly, as in Mexico, the statute can delegate the designation power to the entity supervising the privatization program.

3. Valuing the Enterprise and Preparing It for Sale. Traditionally, the process of valuing the enterprises to be privatized has consisted of either setting a minimum price for the enterprise or allowing the market to set the price. To a minimum price, the supervising entity obtains an independent adviser's valuation of the firm and its assets. Allowing the market to set the price occurs when the supervising entity seeks open bidding for the enterprise with the understanding that, should the bid prices be inadequate, they will be rejected. In either case, the valuation of the enterprise must be accomplished in such a way as to allay any fear that, because of corruption or otherwise, the supervising entity will sell the "national patrimony" to others for a bargain price.

Privatization legislation generally allows the supervising entity to restructure the enterprises in whatever way will make them more efficient and attractive to prospective private-sector purchases. For example, before it was privatized, the Argentine Telephone Company was divided into two companies, TelNorte and TelSur (serving northern and southern Argentina respectively). Restructuring may also include renegotiation or elimination of contracts, wages and benefits, employ- 
ees, elimination of state regulation of the enterprise, or even sale or elimination of some of its assets or divisions.

4. Identifying the Prospective Purchasers. The ideal purchaser of a Latin American publicly owned enterprise is a local investor or investors with enough capital to modernize the enterprise and run it efficiently. Unfortunately, many enterprises being privatized require extensive infusions of capital and technology that local investors are unable to furnish. Thus, foreign capital and foreign investors remain the principal potential purchasers of enterprises being privatized. The fear is, however, that foreign control of the principal productive enterprises in the national economy is against the public interest. The challenge, then, is to encourage the investment of foreign capital and technology in the entities being privatized while ensuring that control of the enterprise remains in local hands.

In response to this challenge, the entities supervising the privatization process have devised a number of ingenious mechanisms, such as:

- requiring the foreign investor bidding for an enterprise to have local partners;

- forbidding the foreign investor to purchase a majority interest in the enterprise; or

- selling the investor nonvoting shares.

In order to alleviate employee and supplier concerns that they will be terminated when the enterprise is privatized, many of the statutes require that the unions representing the employees, the employees themselves, and the enterprise's suppliers and consumers be allowed to purchase, on advantageous terms, a portion of the enterprise.

The Brazilian privatization legislation has identified public pension plans, financial institutions and insurance companies as ideal purchasers of enterprises being privatized. Accordingly, the Brazilian legislation requires all such entities to invest a percentage of their total assets or reserves in Privatization Certificates that must be exchanged for shares of the entities being privatized. Thus, Brazil's financial institutions and pension plans are forced to become the purchasers of that country's public enterprises.

5. The Sale of the Enterprise. The legislation generally gives the entity supervising privatization complete flexibility in choosing the mechanism by means of which the public enterprise will be privatized. The following are some principal mechanisms used in Latin American privatizations:

Private Placement (Brazil). The government, in a negotiated private transaction, sells the stock of a public enterprise to one or more purchasers.

Auction (Argentina, Mexico). The entity supervising privatization requests bids for the public enterprise. Generally, terms for acceptable bids are set forth in advance and may include commitment to maintain jobs and salaries, improve service within certain parameters, or invest a certain amount of money in the enterprise within a certain period, and payment in a designated form (for example, debt-equity conversions) or currency. To forestall fears of corruption, the bid opening and examination are public.

Auction and Secondary Offering. Sometimes, as in the case of Telefonos de Mexico (TELMEX), the original auction of the enterprise will be the first part of a twostep process, the second step being a national or international public stock offering to raise additional capital for modernization of the enterprise.

Sale of Licensing Rights (Argentina, Bolivia). The government will sell the legally protected, exclusive right of a public enterprise to engage in a particular business 
to a private investor for a limited period of time (for example, sale of freight-route rights on Argentine railways and sale of Mexican turnpikes).

Joint Ventures (Argentina). The public enterprise may enter a joint venture agreement with a private entity to exploit a particular segment (or all) of its business.

\section{The Success of Privatization in Latin America}

The success of privatization programs in Latin America has been uneven. Mexico and Argentina, with their highly successful (and widely imitated) privatization programs, have been able to privatize a large number of public enterprises, raise billions of dollars for their public treasuries, and eliminate large amounts of their foreign debt.

At the other extreme, voters in Uruguay, in an unusual referendum, decisively rejected a privatization program on the grounds that privatization would constitute an unacceptable sale of "the national patrimony." Other countries in the region (such as Brazil, Panama and Venezuela) have not successfully implemented their privatization programs. The reasons are many and varied. In some countries (Panama), the manner in which the privatization program will be implemented has not been agreed upon. In other countries (Venezuela), there has been no agreement on which enterprises are to be privatized. In still others (Brazil), the supervising entity has been unable to agree on a minimum bidding price for any public enterprises.

On another plane, there are economic and political reasons for failure of the privatization process: lack of government stability, of confidence in the privatization process, or of economic operational feasibility of the enterprises.

\section{An Emerging International Law of Privatization in Latin America?}

As has been noted in this presentation, most countries in Latin America wishing to participate in World Bank and IMF lending programs have been obligated by those institutions to enact a remarkably similar set of reforms aiming toward free trade, liberalized foreign investment and diminished governmental control of the national economy. Privatization of public enterprises is one of the reforms that these lending sources have insisted upon. In short, the World Bank and the IMF, as loan conditions, insist on the creation of a privatization system that they deem effective and desirable.

As has been noted, the legal framework and implementation of the privatization process has tended to follow the model created by Chile, Argentina and Mexico, for two reasons. First, this "model" has obtained the blessing of the World Bank and the IMF as desirable and thus satisfying their loan conditions. Secondly, the obvious success of this model has inspired other nations in the region to adopt it.

Thus, an "international norm" for the legal framework and implementation of the process of privatization of public enterprises seems to be emerging in Latin America. Whether this emerging international norm will develop into a full fledged "international law of privatization" remains to be seen.

\section{Remarks by Gerhard Wegen*}

I speak to you as a German lawyer, and I will not venture into macroeconomics, or political science or sociology, which I don't know much about. The earlier discussion presented a bouquet of problems, and I have chosen two or three

\footnotetext{
* Of the German and New York Bars; Partner, Gleiss, Lutz, Hootz, Hirsch and Partners, Stuttgart.
} 
because it is not possible to deal with our whole subject in this short time. First, I would like to say a word on the notion of privatization. I will then depict a little of the situation in Germany and compare and contrast this to the situation in other Eastern European states. Finally, I will venture into whether there are developments at the international level emanating from privatization.

Privatization can be looked at from different perspectives, but I think we are dealing here only with the more formal notion-with the change in legal form of an enterprise from a state-owned enterprise to a private entity. That is a formal step, and the next step is to implement private ownership of the enterprise. And I would agree with Professor Farer that for an effective privatization a state-owned enterprise must be decartelized or demonopolized prior to privatization, and regulatory bodies must be set up to deal with the then-privatized entities. I have a very interesting example which frequently recurred in Germany. As you know we had the Western German state and the Eastern German state. When we began to privatize the East German industry, the question often was: Do you want to privatize the Eastern monopolistic enterprise in total, so that you add a new layer to the existing oligopoly in Western Germany? Or will you sell all parts of the former state monopoly to the already active West German enterprises, so that you permanently cement the West German oligopoly also in the East?

I want to remind you briefly of the background in Germany. East Germany (the GDR) agreed to be part of the Federal Republic of Germany by way of accession to the territory of the Federal Republic in several treaties I will not dwell upon now. They were reproduced in the Society publication International Legal Materials. On the legal level, what happened was that, in the first step, German law applied only partially, to the extent East German law either was still based on socialist ideas so that West German law took precedence, or specific laws were introduced in East Germany. In the second step, by the Unification Treaty of October 1990, West German law was introduced in total in the formerly East German territory. The result was that all East German laws were abrogated unless specifically provided for. It is often forgotten that, at the same time, EEC primary and secondary law became applicable in total to East Germany, with few exceptions.

Now, as to Germany in its privatization efforts, I have brought with me some statistics which you may want to examine. What I want to stress is the magnitude of the task in Germany. We installed a fiduciary agency that took formal title to all enterprises in East Germany and to all state-owned properties, which amounted to approximately 12,500 enterprises, 20,000 restaurants and retail shops, and the vast bulk of real estate in East Germany. In the last three years the fiduciary agency has sold about 9,000 enterprises, disposed of 20,000 retail shops and restaurants, and disposed of the bulk of real property, which meant a daily acquisition exercise of approximately twenty companies a day. This huge task was performed in the early days by some 200 East German trained employees and more recently, by approximately 4,000 employees.

Not going into figures further, I want to point out two or three features of the privatization process in East Germany. First, it was basically run on a first-come, first-served basis, which meant that if one was early enough at the fiduciary agency, one would get the desired piece of property or enterprise. With people unaccustomed to public auctions or tender procedures, it was an informal way of serving whoever was best suited in terms of knowing the right people, knowing the management, and the like.

Secondly, the fiduciary agency, unlike the situation in other East European 
states, is a deep pocket: if there are financial obligations, the German state will pay. Whatever the outcome of the privatization effort, the German state or the German taxpayer will stand in. This is different from the situation elsewhere, where the success, so to speak, is felt immediately by everyone.

Thirdly, the fiduciary agency took into account noncash purchase price considerations such as guarantees of employment, obligations to invest money, obligations to continue the business, and other matters. This is fairly uncommon; in a normal privatization the government simply divests. A further specific item in Germany is the problem of restitution of the property to the former owners who were expropriated. So there is a lot of legal uncertainty.

To return to the "deep pocket," I think that Germany was in a peculiar situation because there was a financially sound West German state which added part of the territory of the former German Reich and thus added a host of good and not so good enterprises, so that by virtue of the economic power of the West German industry, the privatization was not seen as a problem. It is now getting worse. In the other Eastern European states it is quite different, because there is no "big brother," there is no other economy to look to if privatization should go wrong.

Now a word with regard to the EEC. Professor Farer alluded to a double standard applied by the EEC, which recommends to East European states that they not have monopolies, whereas we have them in the EEC. That is correct. But I think it is important that the EEC at an early stage try to avoid monopolies and other mistakes under which we are still laboring. The EEC is trying to break up monopolies with regard to telecommunications, transport and other industries, in spite of much resistance by the member states. So I accept the argument, but it is not quite fair.

Let me also say that in Eastern Europe there is a strong tendency to have public tenders and tender procedures, which theoretically makes for a kind of due process or fair hearing of those who want to bid. I think it is correct to state that, unlike the situation in East Germany, in the other Eastern European states there are schemes in place to have the employees participate in the privatization-in particular in Poland, where 20 percent of the shares must be offered to the employees under certain conditions regarding prices and buy-back guarantees; there are voucher systems and other features.

Finally, let me suggest four areas where we may see an impact of privatization on international law-without really reasoning them through because of time. First, I think we may see the development of a general principle of law in the area of procedure. We may see that standards develop and evolve with regard to due process, fair trial and the preconditions for a public auction or tender. This may be argued either under public law and constitutional rights of participants as to a public law auction, or it may be argued under private law similar to developments in the United States in corporate takeovers, where standards have developed regarding fair treatment of shareholders.

Secondly, I think there will be more jurisprudence and more state practice with regard to sovereign immunity. Because many of the privatization agencies are the states themselves, the privatization ministries, or state or quasi-state agencies, I think we will have much more decisional law and state practice in the delineation of acta jure gestionis et jure imperii-of commercial acts and state acts-in the privatization process.

Thirdly, I think we will see much more dispute and dispute settlement in connection with privatization, on two levels: first, in private law, international commercial arbitration between the selling entity and the buyer, be that under ICC Rules, 
UNCITRAL Rules, or whatever rules may be agreed; and also between the states espousing the disputants' claims and the initiating state. We have such a case in Germany, where the home state goes after the host state and says "you are not treating my nationals fairly under our treaties," such as bilateral investment treaties.

Fourthly, we have spent a lot of time to develop a right of states to expropriate or to nationalize, with or without compensation. I wonder whether the right to expropriate may not, or must not, be accompanied by a right or a duty of the same state to privatize or to reprivatize when the conditions for the initial expropriation or the state ownership are no longer present. So we might look at an emerging norm and propose that academics give some thought to the duty of states to privatize industries in certain noncore state activities (if the theory of macroeconomy is correct that efficiency and a livable free marketplace are really warranted only in a materially privatized economy). 


\section{APPENDIX}

\section{More Than 10,000 Privatizations ${ }^{1}$}

In October, the Treuhand was able to conclude another 415 privatizations, raising the total number of privatizations to 10,403 . Of the 12,442 enterprises it had originally, only 3,189 are still in the hands of the Treuhand.

The total amount of approved investment had grown to DM 157.6 billion (of which 30 billion is an electricity contract). Of the 1,331,891 workplaces that have been agreed to, at least 800,000 are also contractually guaranteed. On October 1 , 1992, 549,000 people were still employed in the remaining Treuhand companies. Most of the employees work in industrial enterprises, and more than half of them (ca. 330,000) work in one of the 198 Treuhand enterprises with over 500 employees.

Most of the approved workplaces, incidentally, are in Saxony, the largest East German state. However, in proportion to the overall population, the employment situation looks somewhat better for East Berlin and Brandenburg (see Appendix 1) [omitted here].

The interest of employees or management to take over the responsibility for running the enterprises themselves (MBOs) is unabated. All in all it was possible to conclude a fifth of the privatizations in this way, for a current total of 1,841 (see Appendix 2) [omitted here].

The number of foreign investors grew in October 1992 by 15 for a total of 523 . The foreign investors have agreed to provide 113,321 workplaces and will invest DM 14.3 billion. Over 10,000 workplaces are being secured by investors from France $(18,048)$, Canada $(16,555)$, Switzerland $(15,694)$, Great Britain $(13,340)$, Austria $(11,784)$ and the USA $(10,922)$.

By the end of October 1992, it was decided to shut 1,924 Treuhand enterprises down, involving 269,509 workplaces. As a result of the efforts being made in this regard, it will probably be possible to save 29 percent of these jobs. The most recent example is the privatization of the refrigerator plant ddk Scharfenstein, which had been closed down last summer and is not producing again.

\section{TimOTHY L. WiLliams* RAFIQ Al-Shabaz* Reporters}

\footnotetext{
${ }^{1} 17$ Treuhand Informationen, Dec. 1992 (Mr. Wegen's translation).

* Thurgood Marshall School of Law, Texas Southern University.
} 